\title{
Tubulin Polymerization Inhibitor AEZS 112
}

National Cancer Institute

\section{Source}

National Cancer Institute. Tubulin Polymerization Inhibitor AEZS 112. NCI Thesaurus.

Code C162525.

An orally bioavailable small molecule tubulin polymerization inhibitor with potential antineoplastic activity. Upon oral administration, tubulin polymerization inhibitor AEZS 112 binds to tubulin and prevents its polymerization in tumor blood vessel endothelial cells and tumor cells. This blocks the formation of the mitotic spindle and leads to cell cycle arrest at the G2/M phase. As a result, this agent disrupts the tumor vasculature and tumor blood flow, deprives tumor cells of nutrients and induces tumor cell apoptosis. In addition, this agent has a direct cytotoxic effect on tumor cells by inhibiting tubulin polymerization. 